\title{
The Hepatoprotective and MicroRNAs Downregulatory Effects of Crocin Following Hepatic Ischemia-Reperfusion Injury in Rats
}

\author{
Ghaidafeh Akbari, ${ }^{1}$ Seyyed Ali Mard, ${ }^{2}$ Mahin Dianat, ${ }^{1}$ and Esrafil Mansouri ${ }^{3}$ \\ ${ }^{1}$ Physiology Research Center (PRC), Department of Physiology, School of Medicine, Ahvaz Jundishapur University of \\ Medical Sciences, Ahvaz, Iran \\ ${ }^{2}$ Physiology Research Center (PRC), Research Center for Infectious Diseases of Digestive System, Department of Physiology, \\ School of Medicine, Ahvaz Jundishapur University of Medical Sciences, Ahvaz, Iran \\ ${ }^{3}$ Cellular and Molecular Research Center, Department of Anatomical Sciences, School of Medicine, Ahvaz Jundishapur \\ University of Medical Sciences, Ahvaz, Iran \\ Correspondence should be addressed to Seyyed Ali Mard; mard-sa@ajums.ac.ir
}

Received 27 September 2016; Revised 16 January 2017; Accepted 31 January 2017; Published 6 March 2017

Academic Editor: Kum Kum Khanna

Copyright (C) 2017 Ghaidafeh Akbari et al. This is an open access article distributed under the Creative Commons Attribution License, which permits unrestricted use, distribution, and reproduction in any medium, provided the original work is properly cited.

Background. Liver ischemia-reperfusion (IR) injury is one of the chief etiologies of tissue damage during liver transplantation, hypovolemic shock, and so forth. This study aimed to evaluate hepatoprotective effect of crocin on IR injury and on microRNAs (miR-122 and miR-34a) expression. Materials and Methods. 32 rats were randomly divided into four groups: sham, IR, crocin pretreatment $(\mathrm{Cr})$, and crocin pretreatment + IR $(\mathrm{Cr}+\mathrm{IR})$ groups. In sham and $\mathrm{Cr}$ groups, animals were given normal saline $(\mathrm{N} / \mathrm{S})$ and $\mathrm{Cr}(200 \mathrm{mg} / \mathrm{Kg})$ for 7 consecutive days, respectively, and laparotomy without inducing IR was done. In IR and Cr + IR groups, $\mathrm{N} / \mathrm{S}$ and $\mathrm{Cr}$ were given for 7 consecutive days and rats underwent a partial (70\%) ischemia for $45 \mathrm{~min} / \mathrm{reperfusion}$ for $60 \mathrm{~min}$. Blood and tissue samples were taken for biochemical, molecular, and histopathological examinations. Results. The results showed decreased levels of antioxidants activity and increased levels of liver enzymes improved by crocin. The expression of miR-122, miR$34 \mathrm{a}$, and p53 decreased, while Nrf2 increased by crocin. Crocin ameliorated histopathological changes. Conclusion. The results demonstrated that crocin protected the liver against IR injury through increasing the activity of antioxidant enzymes, improving serum levels of liver enzymes, downregulating miR-122, miR-34a, and p53, and upregulating Nrf2 expression.

\section{Introduction}

Ischemia-reperfusion (IR) injury is one of the most important etiologies of tissue damage following liver transplantation, liver resection interventions, hypovolemic shock, and trauma [1]. In spite of different therapeutic methods including pharmacology, genetic, and surgical protocols for alleviating the side effects of hepatic IR injury, it remains untreatable till now [2].

A series of physiological and biochemical changes occur following hepatic IR injury. The tissue deprivation of oxygen, nutrients, and disruption of the metabolic reactions in the ischemic phase impair mitochondrial activity which result in liver cell injury. Reperfusion in the second phase of
IR exacerbates the tissue function by activating a series of events such as generation of reactive oxygen species (ROS), activation of the inflammatory, and apoptotic mediators [3].

MicroRNAs (miRNAs, miR) are a category of internal noncoding RNAs that posttranscriptionally modulate protein-coding message [4] through binding to the $3^{\prime}$ untranslated region ( $3^{\prime}$-UTR) of target messenger RNAs. They are 21-26 nucleotides in length that derived from precursor that cleaved by two endonucleases; Drosha and Dicer. Drosha, the nuclear enzyme for processing microRNAs, through converting primary microRNA (pri-microRNA) into a 60-70-nucleotide microRNA produces a precursor microRNA (pre-microRNA). Dicer, the cytoplasmic processor of microRNA, cleaves this precursor to generate mature 
microRNA [5]. Various studies showed that microRNAs play an important role in multiple physiological and pathological functions such as differentiation, development, and cancer $[6]$.

miR-122, a 22-nucleotide microRNA, is derived from a RNA transcript from the gene $h c r$ in the liver cells. It accounts for near $70 \%$ of total microRNAs pool in the liver tissue with almost 66000 copies per cell while its expression is rare in other tissues [7]. miR-122 has been shown to exert several effects in liver such as development, hepatic function [8], and hepatocyte growth [9]. It is well known that miR-122 is a noninvasive and early releasing circulating biomarker for determination of hepatic disorders [10]. A previous report showed that there is a close correlation between the serum level of miR-122 and enzymes aspartate aminotransferase (AST) and alanine aminotransferase (ALT) following warm IR-induced liver injury in rats [11]. The serum levels of liver enzymes ALT, AST, and ALP (alkaline phosphatase) have been shown to increase following hepatic IR injury [12]. These levels are the most common parameters which have been applied to manage the hepatic injury [13], while recent studies have demonstrated that miR-122 is a more sensitive parameter in hepatic injury $[14,15]$.

miR-34a is the another microRNA that reflects liver damage [16]. The mature miR-34, a 22-nucleotide microRNA, has three members: miR-34a, miR-34b, and miR-34c. miR-34a is a direct target of p53 [17] which inhibits cell proliferation and regulates liver function [18]. Several studies have shown that miR-34a increases during stress-induced injuries $[19,20]$. It has been shown that inhibition of miR-34a protects the liver function against IR- and nonalcoholic fatty liver disease(NAFLD-) induced injury [21]. Moreover, inhibition of miR34a has been demonstrated to mitigate the pathological changes in other organs such as heart [19], intestine, and lung [22].

Oxidative stress, an oxidant/antioxidant imbalance [23], decreases the levels of antioxidant enzymes including catalase (CAT), superoxide dismutase (SOD), and glutathione peroxidase (GPx), via generation of ROS [24]. The antioxidant enzymes, SOD and CAT with scavenging the intracellular ROS, protect cells against IR-induced injury [25]. In addition, oxygen-derived free radicals are one of the most important causes of cellular damage following IR injury in various organs such as liver, lung, and intestine [23].

Evidences have shown that the function, stability, binding affinity, and integrity of microRNAs may be modified by ROS [26]. The redox status has also been shown to regulate the cleavage of microRNAs. Under the condition of endoplasmic reticulum (ER) stress, a transmembrane endoplasmic kinaseendoribonuclease cleaves precursor of miR-34a which in turn causes apoptosis by upregulating the apoptotic protein caspase $2[27,28]$.

p53 protein is a guardian of genome discovered for the first time in 1979 [29]. It is one of the most important tumor suppressors via inhibition of cell cycle and apoptosis [30]. One study showed that the suppression of p53 leads to a decrease in NAFLD-induced hepatic injury [31]. It is activated by multiple stimuli including DNA injury, administration of cytotoxic drugs, ROS, ultraviolet (UV) radiation, and hypoxia [29].

Nuclear factor-erythroid 2-related factor-2 (Nrf2) as a key transcription factor preserves organs versus oxidativeinduced damage [32]. It is retained in the cytoplasm by keapl, released, and transferred to the nucleus for inducing transcription of antioxidant response element (ARE) which induces gene expression of its downstream targets. Nrf2 has been shown to be important for liver function. The susceptibility of liver to multiple oxidative/electrophilic stresses has been shown to increase in Nrf2 knocked out mice [33]. In addition, due to special Nrf2 target genes in liver, the metabolism and excretion of xenobiotics could be affected by this factor [34]. Evidences have shown that Nrf2 has a protective role against various liver diseases such as cholestatic liver injury [35], viral hepatitis [36], nonalcoholic steatohepatitis [37], NAFLD [38], and drug-induced liver injury [37].

Crocus sativus Linn. or saffron [Iridaceae family] has four major pharmacologically active constituents such as crocin, crocetin, picrocrocin, and safranal. Crocin is a water soluble carotenoid and the most important active constituent of saffron [39]. Crocin, as an antiapoptotic, anti-inflammatory, and antioxidant agent [40], has many beneficial protective effects against renal [41], gastric [42], retinal [43], and brain [44] IR-induced injuries.

The cytoprotective effects of crocin as a potent antioxidant against IR-induced tissue injuries are well established while to best our knowledge its effect on liver IR injury remained to be defined. Therefore, the present study is designed to (1) evaluate the protective effect of crocin pretreatment on IR-induced hepatic injury and (2) investigate its effect on the expression of miR-122 as well as miR-34a following hepatic IR injury.

\section{Materials and Methods}

2.1. Animals. Male Wistar rats $(200-250 \mathrm{~g})$ were purchased from the animal house of Ahvaz Jundishapur University of Medical Sciences, Ahvaz, Iran. Animals were fed on a conventional diets and tap water ad libitum. They were maintained under standard conditions of humidity, temperature (20$24^{\circ} \mathrm{C}$ ), and 12 -h light-dark cycle. Animals were deprived of food, but not water, overnight before experiments. All experiments were performed in accordance with ethics committee of Ahvaz Jundishapur University of Medical Sciences (APRC9421).

2.2. Animal Grouping. In the current study 32 male Wistar rats were randomly assigned into four groups, each consisting of 8 rats. They were sham (S) group: animals received normal saline (N/S; $2 \mathrm{~mL} \mathrm{Kg}^{-1}$ ) [41] for 7 consecutive days, intraperitoneally (ip) [45]; then laparotomy without IR induction was performed. IR group: animals received N/S with the same dose and time; then IR induction was carried out as mentioned before. Crocin $(\mathrm{Cr})$ pretreatment group: $\mathrm{Cr}$ (200 $\mathrm{mg} \mathrm{Kg}^{-1}$, ip) was given prior to intervention for 7 consecutive days [46]; then laparotomy without IR induction 
was done. $\mathrm{Cr}+\mathrm{IR}$ group: animals received $\mathrm{Cr}$ with the same dose and time and was then subjected to IR induction.

2.3. Surgical Procedure. The rats anesthetized using a mixture of ketamine and xylazine (Alfasan Co. Woerden-Holland, 80 $+10 \mathrm{mg} \mathrm{Kg}^{-1}$, ip, respectively) [47]. Partial (70\%) ischemia was induced for $45 \mathrm{~min}$ followed by reperfusion for $60 \mathrm{~min}$ as described previously [48].

At the end of experiment, rats were killed by cardiac puncture and two samples of liver tissue were taken, rinsed with $\mathrm{N} / \mathrm{S}$, snap-frozen in liquid nitrogen, and stored at $-80^{\circ} \mathrm{C}$. One sample was used for measurement of protein expression of p53 and another for antioxidants assay. In addition, pieces of liver were fixed in the formalin $10 \%$ solution for histopathological and immunohistochemical evaluations.

2.4. MicroRNAs Extraction and cDNA Synthesis. Total microRNAs were extracted from the frozen serum samples using miRNeasy/Plasma kit (QIAGEN, GmbH, Germany) according to the manufacturer's protocol. The concentration and purity of RNA were determined by spectrophotometry at wavelengths 260 and $280 \mathrm{~nm}$ (Nanodrop Thermo Scientific S.N:D015). The cDNA was synthesized from one microgram of the total RNA using miScript II RT Kit (QIAGEN, GmbH, Germany) according to the manufacturer's instructions.

2.5. Quantitative Real-Time PCR. The expression levels of microRNAs were measured by quantitative real-time polymerase chain reaction (qRT-PCR) using a Light Cycler $^{\circledR} 96$ Real-Time PCR System (Roche Diagnostics, Indianapolis, IN, USA). All PCR amplifications were performed in duplicate reactions and in final volume of $20 \mu \mathrm{L}$ containing $2 \mu \mathrm{L}$ cDNA, $10 \mu \mathrm{L} 2 \mathrm{x}$ QuantiTect SYBR Green PCR Master Mix, $2 \mu \mathrm{L}$ 10x miScript Primer Assay [miR-122 (MS00000315), or miR34a (MS00000224); QIAGEN], $2 \mu \mathrm{L}$ 10x miScript Universal Primer [(MS0003374); (QIAGEN)], and $4 \mu \mathrm{L}$ RNAase free water using the following protocol: initial activation step at $95^{\circ} \mathrm{C}$ for $15 \mathrm{~min}$ to activate HotStar Taq DNA polymerase followed by 45 cycles at $94^{\circ}$ for $15 \mathrm{~s}, 55^{\circ} \mathrm{C}$ for $30 \mathrm{~s}$, and $70^{\circ} \mathrm{C}$ for $30 \mathrm{~s}$. In addition, the no-template negative control $\left(\mathrm{H}_{2} \mathrm{O}\right)$ was routinely run in every PCR. The levels of microRNAs expression were normalized with RNU6 (as an internal control) and the fold change was calculated using the $2^{-\Delta \Delta \mathrm{Ct}}$.

2.6. Protein Extraction. Frozen liver tissue was extracted using RIPA buffer ( $25 \mathrm{mM}$ Tris- $\mathrm{HCl} \mathrm{pH}$ 7.6, $150 \mathrm{mM} \mathrm{NaCl}$, $1 \%$ NP- $40,1 \%$ sodium deoxycholate, and $0.1 \%$ SDS) containing protease inhibitor cocktail (complete mini, Roche, Indianapolis, IN, USA). To analyze the protein fraction, protein obtained using RIPA buffer, from liver samples, was resuspended in $1 \%$ SDS. The total recovery and integrity of these fractions were determined by Bradford assay and SDSpolyacrylamide gel electrophoresis.

2.7. Western Blotting Analysis. The extracted frozen liver proteins were separated by SDS-PAGE on $12 \%$ acrylamide gels and transferred onto a nitrocellulose membrane. The membranes were blocked with $5 \%$ nonfat dry milk dissolved in tris-buffered saline (TBS) with $0.1 \%$ Tween 20 (TBST, pH: 7.6) for $6 \mathrm{~h}$ and then incubated overnight at $4^{\circ} \mathrm{C}$ with antip53 antibody (mouse monoclonal, dilution 1: 200; Santa Cruz Biotechnology; SC-100), or anti-beta actin antibody (mouse monoclonal, dilution 1:5000; Abcam [ab20272], USA) was added to the membrane. After 5 times of washing with TBST, membranes were incubated with a rabbit polyclonal secondary antibody to mouse IgG HRP, dilution 1:7000, for $90 \mathrm{~min}$ at room temperature. Labeled proteins were detected using a chemiluminescence western blotting system. The expression of studied proteins was semiquantified by Image $\mathrm{J}$ analysis software and the values were normalized to $\beta$-actin as a housekeeping protein.

2.8. Biochemical Assay of Liver Enzymes. The blood samples were centrifuged at $3000 \mathrm{rpm}, 10$ minutes, to separate the serum samples and stored at $-20^{\circ} \mathrm{C}$ until analysis. The serum levels of liver enzymes ALT, AST, and ALP were measured using commercial kits (Pars Azmoon, Iran) according to the manufacturer's instructions by a serum autoanalyzer (BT1500-A-A, Rome, Italy).

2.9. Assessment of the Activity of Antioxidants. The activity of superoxide dismutase, catalase, and glutathione peroxidase in the liver homogenates was measured using commercial kits (Zellbio GmbH, Germany) according to the manufacturer's instructions.

2.10. Histopathological Analysis. For histological evaluations, the liver tissues were fixed in 10\% neutral formalin solution. After $72 \mathrm{~h}$ of fixation, tissues were dehydrated through a series of graded alcohol, embedded in paraffin, and cut into $5 \mu \mathrm{m}$ sections using a microtome (Leica RM 2125, Leica Microsystems Nussloch GmbH, Germany) and stained with hematoxylin and eosin (H\&E) [49]. The images were taken and assessed using a digital research microscope (BMZ-04DZ, Behin Pajouhesh ENG. CO., Iran).

2.11. Immunohistochemistry (IHC) Analysis. Formalin fixed and paraffin embedded $5 \mathrm{~m} \mu$ sections of liver were applied for this procedure.

Following deparaffinization, heat-induced antigen retrieval was done through immersion of slides in $\mathrm{pH} 6.0$ citrate buffer for 10-20 min [50]. Thereafter, sections were incubated with rabbit polyclonal antibody against Nrf2 (dilution 1:100; Abcam [ab31163], USA) and then incubated with a secondary antibody (dilution 1:1000; Abcam [ab6721], USA), in a moist chamber. The reaction was developed with a diaminobenzidine (DAB), sigma [D5637] chromogen solution, and slides were counterstained with hematoxylin. The images were taken and assessed using a digital research microscope (BMZ-04-DZ, Behin Pajouhesh ENG. CO., Iran).

2.12. Statistical Analysis. All data are shown as mean \pm standard errors of the means (SEMs). For comparison among three or more groups was used one-way analysis of variance (ANOVA), followed by Dennett's or LSD post hoc tests. $P<$ 0.05 was considered statistically significant. 


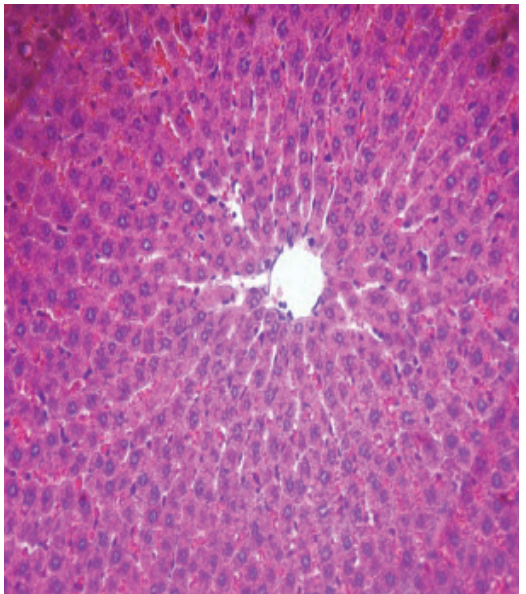

(a)

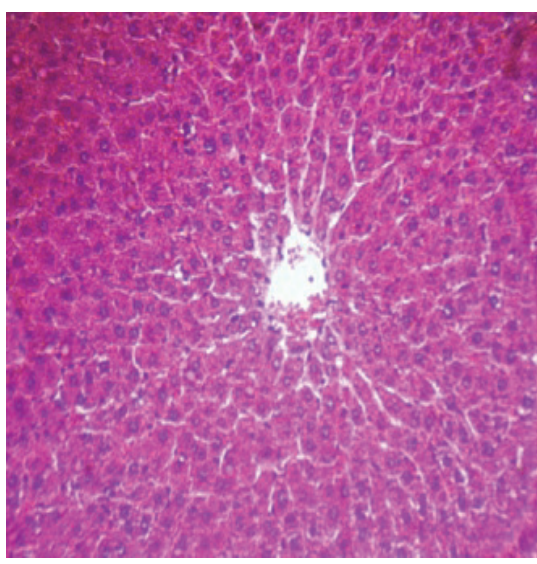

(c)

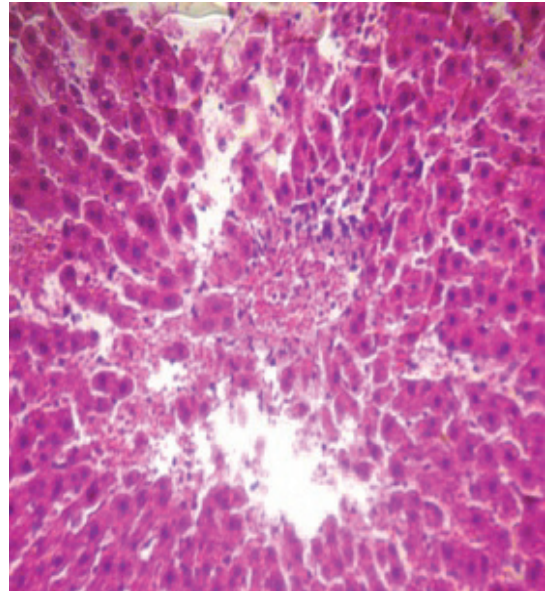

(b)

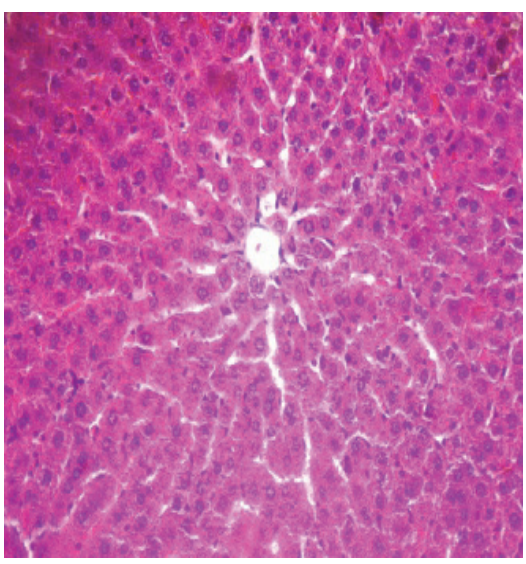

(d)

FIGURE 1: Representative microscopic images (magnification $\times 300$ ) of H\&E stained liver sections following hepatic IR injury. (a) Sham group shows normal appearance and there were not any histopathological changes in liver tissue; (b) IR group shows many histopathological changes including structural disarrangement of liver parenchyma, vascular congestion, central vein dilation (CV), and necrotic cells; (c) Cr group shows normal architecture; and (d) $\mathrm{Cr}+\mathrm{IR}$ group, except mild dilated sinusoids, restored histopathological changes to approximately normal compared to IR group.

\section{Results}

3.1. Crocin Pretreatment Protects the Rat's Liver against Ischemia-Reperfusion Injury. As shown in Figure 1, many histopathological alterations including structural disarrangement of liver parenchyma, vascular congestion, dilation of central vein (CV), and necrotic cells were evident after $45 \mathrm{~min}$ ischemia followed by $60 \mathrm{~min}$ reperfusion (Figure 1(b)). Crocin pretreatment at $200 \mathrm{mg} / \mathrm{Kg}$ for seven consecutive days effectively prevented the structural changes induced by hepatic IR injury as evidenced by mild sinusoids dilation (Figure 1(d)). As shown in Figures 1(a) and 1(c), the structure of tissue liver was normal in the sham and Cr groups.

3.2. Effect of Crocin Pretreatment on the Expression of Nrf2 in Liver after IR Injury. As shown in Figure 2, our IHC study demonstrated that protein expression of $\mathrm{Nrf} 2$ in IR group decreased in cytoplasm and moderately increased in nucleus. The protein expression of Nrf2 upregulated in cytoplasm of sham and $\mathrm{Cr}$ groups, while in $\mathrm{Cr}+\mathrm{IR}$ group the immune reaction increased both in nucleus and in cytoplasm but was in nucleus higher than in cytoplasm.

\subsection{Effect of Hepatic IR Injury and Crocin Pretreatment on} the Serum Levels of miR-122 and miR-34a. As demonstrated in Figures 3(a) and 3(b), according to qRT-PCR results, the serum levels of miR-122 and miR-34a were significantly increased following hepatic IR injury. Crocin pretreatment (200 mg/Kg, ip, for seven consecutive days) significantly decreased these levels $(P<0.01$ and $P<0.001$, respectively). In the sham group, the levels of miR-122 and miR-34a were minimal $(P<0.001$ in both cases $)$.

3.4. Crocin Pretreatment Improved the Activities of GPx, CAT, and SOD Following Hepatic IR Injury. As shown in Figures 4(a)-4(c), the activity levels of GPX, CAT, and SOD in IR group were significantly lower than in the sham group $(P<$ 

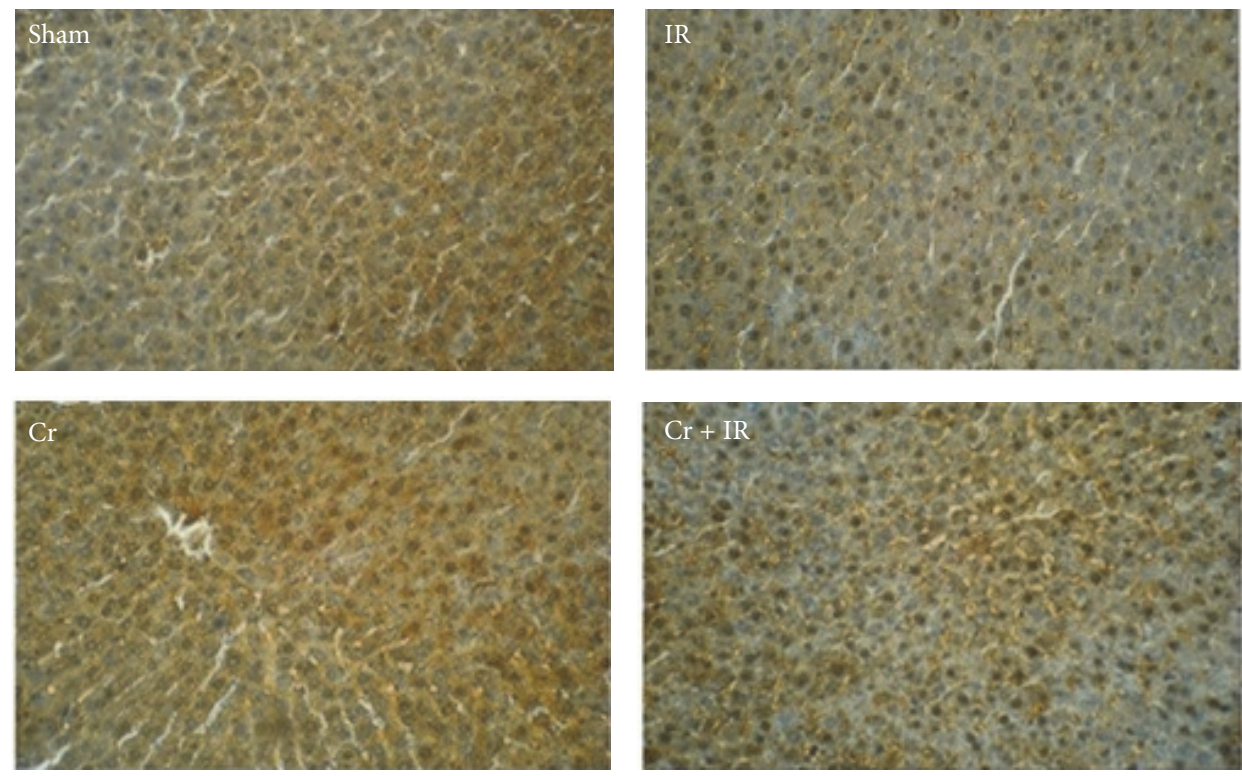

FIGURE 2: Immunohistochemical staining of liver Nrf2 expression (immunohistochemistry, $\times 300$ ). Sham group: Nrf2 localized predominantly in cytoplasm of hepatocytes. IR group: Nrf2 expression decreased in cytoplasm and moderately increased in nucleus. Cr group: The immune reaction was moderate in cytoplasm. Cr + IR group: Nrf2 expression increased both in nucleus and in cytoplasm, but its expression was in nucleus higher than in cytoplasm.

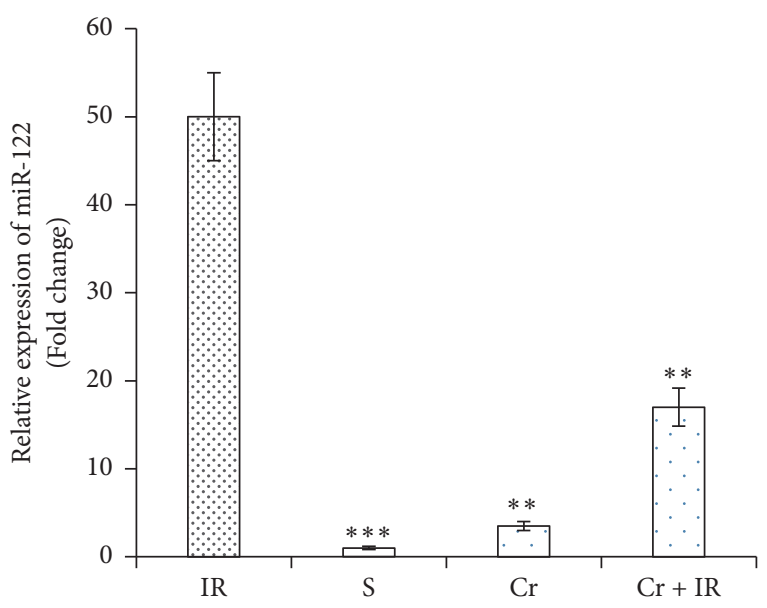

(a)

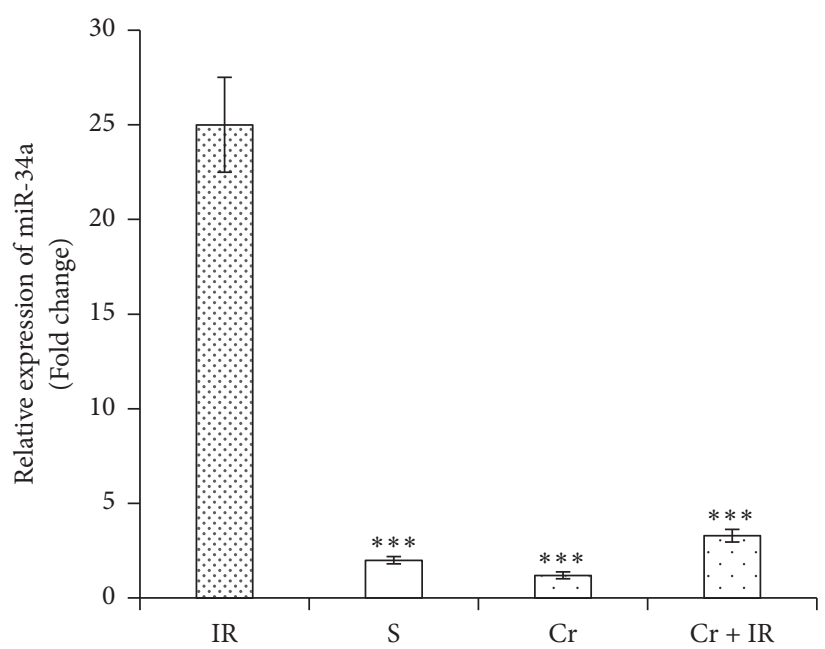

(b)

FIGURE 3: The effect of crocin pretreatment $(200 \mathrm{mg} / \mathrm{Kg}$, ip, for seven consecutive days) on the serum levels of miR-122 (a) and miR-34a (b) following hepatic IR injury. Analysis of the qRT-PCR results showed that the serum levels of miR-122 and miR-34a in Cr + IR rats were significantly lower than in IR group. Data were expressed as relative fold expression compared to IR. ${ }^{* *} P<0.01$ and ${ }^{* * *} P<0.001$ significant difference versus the IR group. IR: ischemia/reperfusion group; S: sham group; Cr: crocin pretreatment group; and Cr + IR: animals received crocin at $200 \mathrm{mg} / \mathrm{Kg}$ (ip) for seven consecutive days prior to induction of IR.

$0.01, P<0.05$, and $P<0.05$, respectively). Pretreatment with crocin (200 mg/kg, ip, seven consecutive days) restored these levels to normal. The highest levels of antioxidant activities were observed in $\mathrm{Cr}$ rats.

3.5. Crocin Pretreatment Decreased the Serum Levels of AST, $A L T$, and ALP Following Hepatic IR Injury. Figures 5(a) and 5(b) show that following IR injury, the serum levels of AST and ALT in IR group were significantly higher than in the sham group $(P<0.001$ and $P<0.05$, respectively). These levels in $\mathrm{Cr}+\mathrm{IR}$ group were significantly lower than in the IR group $(P<0.01$ in both cases). As illustrated in Figures 5(a) and 5(b), there were no differences between the serum levels of AST and ALT in Cr and sham groups. The results also demonstrated that $45 \mathrm{~min}$ ischemia followed by $60 \mathrm{~min}$ reperfusion increased the serum level of ALP (Figure 5(c)). This level in sham group was significantly lower than in IR group $(P<0.001)$. Pretreatment with crocin $(200 \mathrm{mg} / \mathrm{Kg}$, 


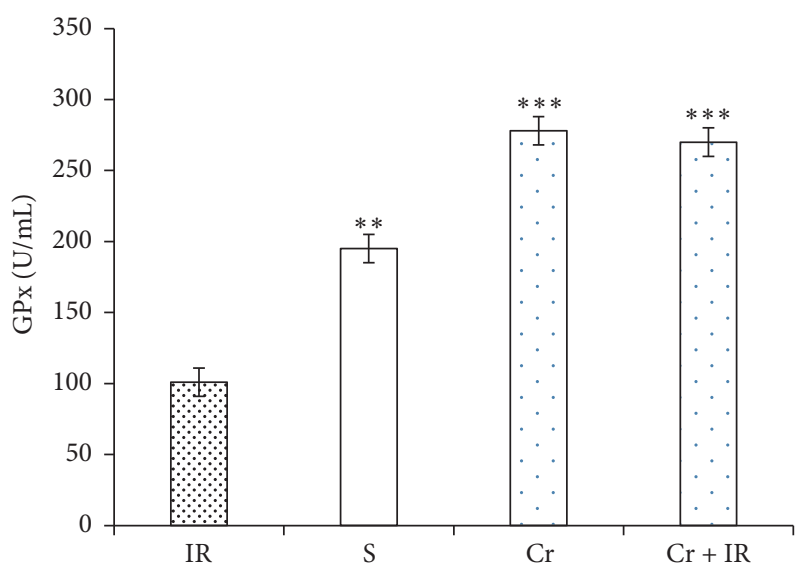

(a)

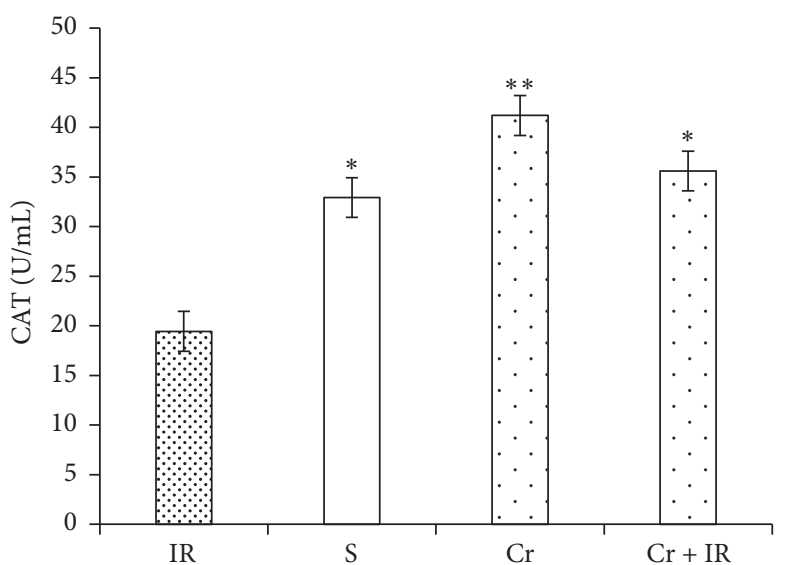

(b)

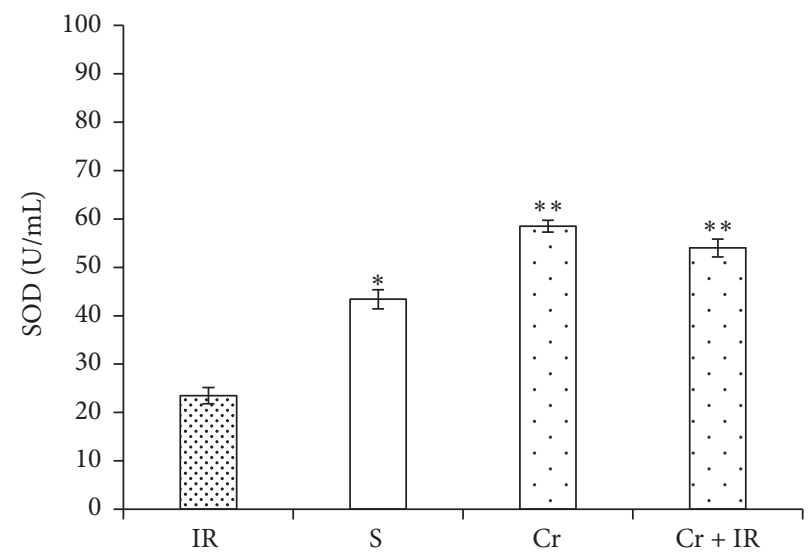

(c)

FIGURE 4: The effects of crocin pretreatment on antioxidant activity of GPx (a), CAT (b), and SOD (c) following hepatic IR injury. The levels of antioxidant activity of GPX, CAT, and SOD in IR rats were significantly lower than in sham group. Pretreatment with crocin restored these levels to normal. Results are expressed as mean \pm SEM. ${ }^{*} P<0.05$ and ${ }^{* *} P<0.01$ significant difference versus the IR group. GPx: glutathione peroxidase; SOD: superoxide dismutase; CAT: catalase. Cr: crocin pretreatment; IR: ischemia/reperfusion; S: sham; Cr + IR: animals received crocin at $200 \mathrm{mg} / \mathrm{Kg}$ (ip) for seven consecutive days prior to induction of IR; U/L: unit per liter. ${ }^{* * *} P<0.001$.

ip, seven consecutive days) significantly reduced this level to near normal $(P<0.01)$ (Figure 6).

3.6. Crocin Pretreatment Downregulated the Protein Expression of p53 Following Hepatic IR Injury. As illustrated in Figure 7 , the level of protein expression of p53 in IR group was significantly higher than in sham, $\mathrm{Cr}$, and $\mathrm{Cr}+\mathrm{IR}$ groups. Pretreatment with crocin $(200 \mathrm{mg} / \mathrm{Kg}$, ip, seven consecutive days) prior to induction of IR significantly reduced this level to near normal in comparison with IR group.

\section{Discussion}

The present research showed that crocin $(\mathrm{Cr})$ protects the rat's liver against IR injury. The results of the current study showed that crocin (a) decreased the increased serum levels of miR-122 and miR-34a in rats following IR-induced injury; (b) downregulated the protein expression of p53 in the liver; (c) decreased the increased serum levels of liver enzymes; (d) increased the decreased level of antioxidant activity of SOD,
GPx, and CAT in the liver; (e) mitigated the histopathological changes induced by hepatic IR injury; and (f) increased Nrf2 expression.

The serum level of hepato-specific miR [miR-122] has been shown to increase faster than the serum concentrations of ALT and AST enzymes following hepatic IR injury [51]. Our qRT-PCR results showed that the serum level of miR122 enhanced after IR-induced liver injury. The present findings also showed that crocin pretreatment decreased the overexpression of miR-122 induced by IR injury. There is not any report about the effect of crocin on serum levels of miR122. Therefore, it seems that this effect of crocin pretreatment on the level of miR-122 expression could be secondary to its cytoprotective activity as demonstrated by histopathological findings.

The present histopathological findings showed that pretreatment with $\mathrm{Cr}$ effectively but not completely prevents deleterious effect of IR-induced injury in the rat liver. The qRT-PCR results showed that the serum levels of miR-122 in $\mathrm{Cr}+\mathrm{IR}$ rats were significantly decreased but it was 


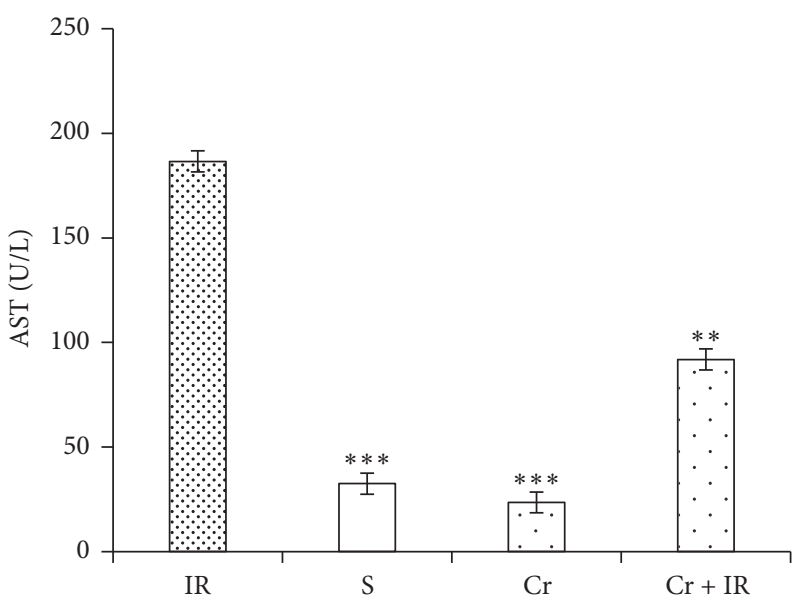

(a)

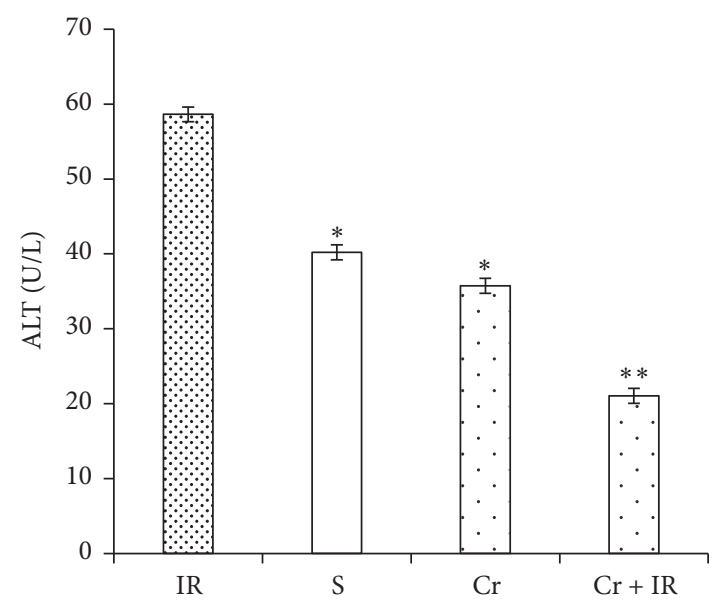

(b)

FIGURE 5: Effects of crocin pretreatment on serum levels of AST (a) and ALT (b) following hepatic IR injury. The results showed that the crocin pretreatment $(200 \mathrm{mg} / \mathrm{Kg}$, ip, seven consecutive days) decreased the serum levels of AST and ALT in comparison with IR group. Results are expressed as mean \pm SEM. ${ }^{*} P<0.05,{ }^{* *} P<0.01$, and ${ }^{* * *} P<0.001$ significant difference versus the IR group. AST: aspartate aminotransferase and ALT: alanine aminotransferase. Cr: crocin pretreatment; IR: ischemia/reperfusion; S: sham; Cr +IR: animals received crocin at $200 \mathrm{mg} / \mathrm{Kg}$ (ip) for seven consecutive days prior to induction of IR; U/L: unit per liter.

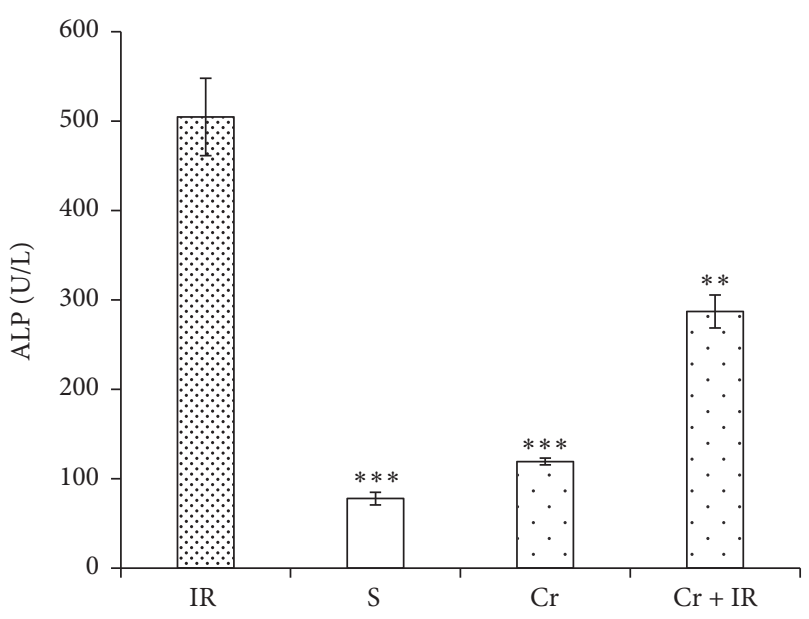

FIGURE 6: Effects of crocin pretreatment on serum level of ALP following hepatic IR injury. The results showed that the crocin pretreatment $(200 \mathrm{mg} / \mathrm{Kg}$, ip, seven consecutive days) decreased the serum levels of ALP in comparison with IR group. Results expressed as mean \pm SEM. ${ }^{* *} P<0.01$ and ${ }^{* * *} P<0.001$ versus IR group. ALP: alkaline phosphatase; Cr: crocin pretreatment; IR: ischemia/reperfusion; S: sham; $\mathrm{Cr}+\mathrm{IR}$ : animals received crocin at dose $200 \mathrm{mg} / \mathrm{Kg}$ (ip) for seven consecutive days prior to induction of IR; U/L: unit per liter.

still higher than that in the sham group. Our results also showed that the highest and lowest levels of miR-122 were, respectively, observed in IR and sham groups. As evidenced by the current histopathological and qRT-PCR results, there is a close correlation between the serum level of miR-122 and severity of liver tissue damage. Therefore, these findings taken together suggest that the monitoring of the serum level of miR-122 could be a high sensitive, early, accurate, and reliable biomarker for determining the progression of liver injuries.
The present qRT-PCR results also showed that the serum level of miR-34a increased following hepatic IR injury. Bader has demonstrated that miR-34a elevated after IR-induced liver injury in rats [52]. It has been shown that the expression of miR-34a is involved in age-related loss of antioxidant defense system in the liver [53]. Moreover, the involvement of miR-34a in age-related loss of antioxidant defense system has been reported [54]. Nrf2 plays an antioxidant agent by regulating the gene expression of antioxidant enzymes [21]. A study showed that the activity of Nrf2 and its ARE target in liver is inhibited by miR-34a [54].

Our results showed that there is an inverse correlation between the serum level of miR-34a and Nrf2. The highest level of miR-34a and lowest level of Nrf2 were observed in IR group. In addition, the present results also showed that there is a direct correlation between antioxidants activity and the level of Nrf2 expression. These results together suggest that miR-34a by inhibiting the activity of $\mathrm{Nrf} 2$ and its downstream target genes decreased the activity of antioxidants. ROS have been documented to affect the expression of microRNAs in an in vitro experiment $[55,56]$. Therefore, the increased production of ROS following IR injury [57] could be the other mechanism caused to the overexpression of miR-34a.

Therefore, on one hand, the accumulation of intracellular ROS by hepatic IR injury as evidenced by a previous study [57] and, on the other hand, the reduction of antioxidant activity as shown by the present results both contribute to the tissue damage in the rat's liver.

The current results also showed that crocin pretreatment decreased the expression levels of miR-34a and increased the activity of antioxidant enzymes.

As mentioned earlier, the level of Nrf2 expression decreased following hepatic IR injury. This level increased by crocin pretreatment. Our findings are in agreement with an in vitro study which showed that crocin increases the expression 

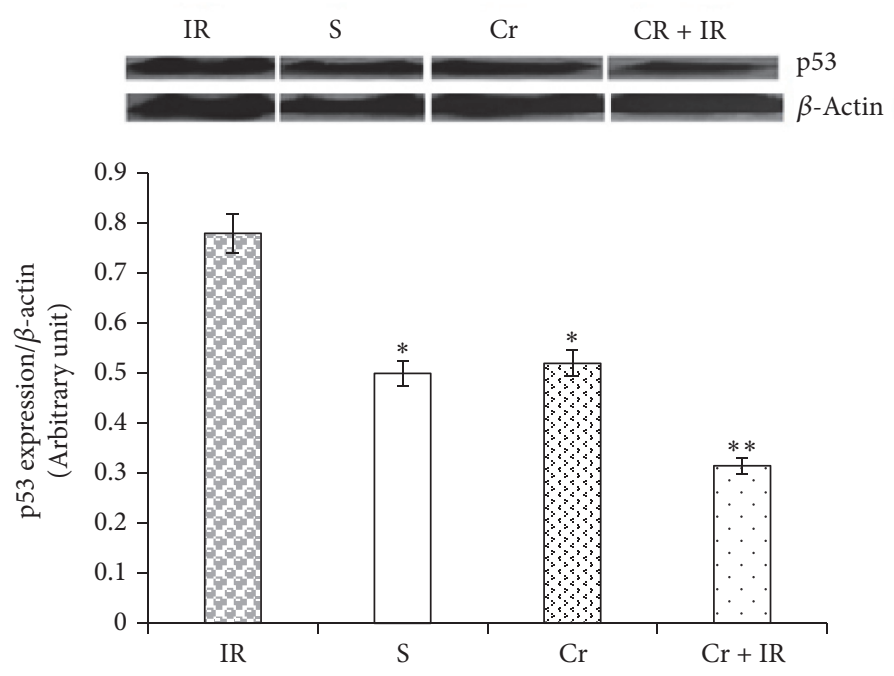

FIGURE 7: Effects of crocin pretreatment on protein expression of p53 following hepatic IR injury. Analysis of western blot results showed that the level of protein expression of p53 in IR group was significantly higher than in sham, $\mathrm{Cr}$, and $\mathrm{Cr}+\mathrm{IR}$ groups. Crocin pretreatment significantly decreased this level to near normal. Results expressed as mean \pm SEM. ${ }^{*} P<0.05$ and ${ }^{* *} P<0.01$ versus the IR group. Cr: crocin pretreatment; IR: ischemia/reperfusion; S: sham; Cr + IR: animals received crocin at $200 \mathrm{mg} / \mathrm{Kg}$ (ip) for seven consecutive days prior to induction of IR.

and activity of Nrf2 in Hela cells [58]. Recently, in one study, authors have shown that crocin pretreatment protects the gastric mucosa against IR-induced injury through upregulating the mRNA expression and activity of antioxidant enzymes in rats [59]. The present results also showed that the activity of all studied antioxidant enzymes [SOD, CAT, and GPx] increased after crocin pretreatment. These findings together suggest that the promotion of Nrf2 by crocin decreased IRinduced ROS accumulation which led to downregulating the expression of miR-34a.

It has been shown there is a positive correlation between p53 and miR-34a via SIRT1-p53 pathway which regulates apoptosis [60]. Another mechanism contributing in apoptosis is Let-7/CD95/p53/miR-34a pathway [61]. Additionally, it was identified that induction of miR-34a as a fine tuning of gene expression by p53 significantly leads to changes such as apoptosis and regulation of cell cycle [62]. On the other hand, a study indicated that chemical suppression of p53 inhibits miR-34a upregulation and dramatically decreased oxidative stress, apoptosis, and hepatic steatosis [31].

Our study also demonstrated that crocin pretreatment decreased the overexpression of $\mathrm{p} 53$ and miR-34a following hepatic IR injury. Therefore, these findings suggest that crocin similar to carnosic acid [63] and hydrogen sulfide [54] through silencing the expression of miR-34a protects the rat liver by inhibiting apoptosis against IR-induced cell injury. P53 [a stress-related transcription factor] by activating Drosha facilitates the processing of pri-miR-34a to pre-miR34a. Therefore, p53 increases the expression level of miR$34 \mathrm{a}[64,65]$. These reports suggest that the lower expression of miR-34a in crocin pretreated rats could be due to the inhibitory effect of crocin on p53 expression.

It has been shown that the serum levels of AST and ALT increase following IR-induced liver injury [66, 67]. In addition, ALP as a performance parameter of liver injury has been shown to elevate after drug-induced hepatotoxicity [68]. These enzymes were released from hepatocytes and elevated in serum during necrosis, structural damage, or cellular leakage [13]. Crocin decreases the concentrations of these enzymes following drug-induced liver damage [13]. The present findings showed that crocin pretreatment decreased the increased serum levels of these enzymes. As seen in Figures 4(a)-4(c), the highest enzymatic antioxidants activity was seen in crocin pretreatment rats. These results showed that administration of crocin as a potent antioxidant for a week effectively enhanced the antioxidant capacity in liver tissue.

Tumor protein 53 [p53] is a guardian of genome induced by DNA damage, ROS, hypoxia and overexpression of oncogenic agents that lead to cell cycle arrest and apoptosis [24, 69]. One survey showed contribution of free radicals in p53 activation and eventually apoptosis [70]. Our results showed that the expression of p53 increased following IR injury. The findings of the present study suggest that this increase could be in part due to attenuation of the antioxidant activities secondary to ROS accumulation.

Crocin has been reported to protect the rats liver against cisplatin-induced toxicity through downregulating the protein expression of p53 [24]. In agreement, our western blot result showed that the IR-induced overexpression of p53, effectively prevented by crocin pretreatment. Therefore, crocin through downregulating the expression of an apoptotic protein [p53] protected the rats liver against IR injury. What is the clinical implication of the present results? The findings of the present study showed that crocin as a potent antioxidant through downregulating miR-122 and miR-34a effectively controls ROS-induced liver injury. Miravirsen has been shown to treat $\mathrm{HCV}$ infection through functionally 
inhibiting miR-122 [71]. Therefore, targeting microRNAs by reducing their expression as performed by crocin in this research and also carnosic acid and hydrogen sulfide in previous reports or inhibition of them as showed by Suzuki et al. [71] both can be effective for treating the liver disorders.

\section{Conclusion}

The results of the present study showed that crocin pretreatment (1) protected the rat's liver against hepatic IR-induced injury; (2) upregulated the protein expression of Nrf2; (3) downregulated the expression levels of miR-122 and miR34a; (4) improved the liver enzymes AST, ALT, and ALP; (5) increased the antioxidant activity of SOD, GPx, and CAT; and (6) decreased the protein expression of p53 following hepatic IR-induced injury.

\section{Competing Interests}

All authors declare that they have no conflict of interests.

\section{Acknowledgments}

The authors would like to gratefully acknowledge the financial support of the Vice Chancellor of Research Affairs of Ahvaz Jundishapur University of Medical Sciences (Grant no. APRC-9421), Ahvaz, Iran.

\section{References}

[1] N. C. Teoh and G. C. Farrell, "Hepatic ischemia reperfusion injury: pathogenic mechanisms and basis for hepatoprotection," Journal of Gastroenterology and Hepatology, vol. 18, no. 8, pp. 891-902, 2003.

[2] E. A. Khowailed, H. A. Mubarak, H. A. Seddeek et al., "Protectiv xanthine oxidase inhibition on ischemia/reperfusion injury in rat liver," The Medical Journal of Cairo University, vol. 79, no. 2, pp. 667-677, 2011.

[3] J. R. Klune and A. Tsung, "Molecular biology of liver ischemia/reperfusion injury: established mechanisms and recent advancements," Surgical Clinics of North America, vol. 90, no. 4, pp. 665-677, 2010.

[4] C. Bernardi, U. Soffientini, F. Piacente, and M. G. Tonetti, "Effects of microRNAs on fucosyltransferase 8 (FUT8) expression in hepatocarcinoma cells," PLOS ONE, vol. 8, no. 10, Article ID e76540, 2013.

[5] S. Li, J. Zhu, H. Fu et al., "Hepato-specific microRNA-122 facilitates accumulation of newly synthesized miRNA through regulating PRKRA," Nucleic Acids Research, vol. 40, no. 2, pp. 884-891, 2012.

[6] A. E. Erson and E. M. Petty, "MicroRNAs in development and disease," Clinical Genetics, vol. 74, no. 4, pp. 296-306, 2008.

[7] J. Chang, E. Nicolas, D. Marks et al., "miR-122, a mammalian liver-specific microRNA, is processed from hcr mRNA and maydownregulate the high affinity cationic amino acid transporter CAT-1," RNA Biology, vol. 1, no. 2, pp. 106-113, 2004.

[8] M. Castoldi, M. V. Spasic, S. Altamura et al., "The liverspecific microRNA miR-122 controls systemic iron homeostasis in mice," Journal of Clinical Investigation, vol. 121, no. 4, pp. 1386-1396, 2011.
[9] F. Fornari, L. Gramantieri, C. Giovannini et al., "MiR-122/cyclin G1 interaction modulates p53 activity and affects doxorubicin sensitivity of human hepatocarcinoma cells," Cancer Research, vol. 69, no. 14, pp. 5761-5767, 2009.

[10] R. Siaj, V. Sauer, S. Stöppeler et al., "Longitudinal analysis of serum miR-122 in a rat model of Wilson's disease," Hepatology International, vol. 6, no. 4, pp. 770-777, 2012.

[11] P. Caster, T. Brandenburger, T. Strahl et al., "Circulating microRNA-122, -21 and -223 as potential markers of liver injury following warm ischaemia and reperfusion in rats," Molecular Medicine Reports, vol. 12, no. 2, pp. 3146-3150, 2015.

[12] M. P. Parikh, A. M. Patel, K. V. Ptel et al., "Protective effect of Momordica charantia against hepatic ischemic reperfusion injury model in rats," Austin Journal of Pharmacology and Therapeutics, vol. 3, no. 1, p. 1064, 2015.

[13] C. Jalili, H. Tabatabaei, S. Kakaberiei, S. Roshankhah, and M. R. Salahshoor, "Protective role of crocin against nicotine-induced damages on male mice liver," International Journal of Preventive Medicine, vol. 6, no. 1, p. 92, 2015.

[14] O. F. Laterza, M. G. Scott, P. W. Garrett-Engele, K. M. Korenblat, and C. M. Lockwood, "Circulating miR-122 as a potential biomarker of liver disease," Biomarkers in Medicine, vol. 7, no. 2, pp. 205-210, 2013.

[15] H. Shifeng, W. Danni, C. Pu, Y. Ping, C. Ju, and Z. Liping, "Circulating liver-specific mir-122 as a novel potential biomarker for diagnosis of cholestatic liver injury," PLOS ONE, vol. 8, no. 9, Article ID e73133, 2013.

[16] S. Cermelli, A. Ruggieri, J. A. Marrero, G. N. Ioannou, and L. Beretta, "Circulating microRNAs in patients with chronic hepatitis C and non-alcoholic fatty liver disease," PLoS ONE, vol. 6, no. 8, Article ID e23937, 2011.

[17] M. Rokavec, H. Li, L. Jiang, and H. Hermeking, "The p53/miR34 axis in development and disease," Journal of Molecular Cell Biology, vol. 6, no. 3, pp. 214-230, 2014.

[18] K. Mcdaniel, L. Herrera, T. Zhou et al., "The functional role of microRNAs in alcoholic liver injury," Journal of Cellular and Molecular Medicine, vol. 18, no. 2, pp. 197-207, 2014.

[19] B. C. Bernardo, X.-M. Gao, C. E. Winbanks et al., "Therapeutic inhibition of the miR-34 family attenuates pathological cardiac remodeling and improves heart function," Proceedings of the National Academy of Sciences of the United States of America, vol. 109, no. 43, pp. 17615-17620, 2012.

[20] Y. Xu, M. Zalzala, J. Xu, Y. Li, L. Yin, and Y. Zhang, "A metabolic stress-inducible miR-34a-HNF $4 \alpha$ pathway regulates lipid and lipoprotein metabolism," Nature Communications, vol. 6, article 7466, 2015

[21] T. Zeng, C.-L. Zhang, F.-Y. Song et al., "The activation of HO$1 / \mathrm{Nrf}-2$ contributes to the protective effects of diallyl disulfide (DADS) against ethanol-induced oxidative stress," Biochimica et Biophysica Acta - General Subjects, vol. 1830, no. 10, pp. 48484859, 2013.

[22] G. Wang, J. Yao, Z. Li et al., "MiR-34a-5p inhibition alleviates intestinal ischemia/reperfusion-induced reactive oxygen species accumulation and apoptosis via activation of SIRT1 signaling," Antioxidants and Redox Signaling, vol. 24, no. 17, pp. 961-973, 2016.

[23] R. De Paola, C. Muià, E. Mazzon et al., "Effects of Hypericum perforatum extract in a rat model of ischemia and reperfusion injury," Shock, vol. 24, no. 3, pp. 255-263, 2005.

[24] Y. Sun, J. Yang, L.-Z. Wang, L.-R. Sun, and Q. Dong, "Crocin attenuates cisplatin-induced liver injury in the mice," Human and Experimental Toxicology, vol. 33, no. 8, pp. 855-862, 2014. 
[25] Y. Yabe, N. Kobayashi, T. Nishihashi et al., "Prevention of neutrophil-mediated hepatic ischemia/reperfusion injury by superoxide dismutase and catalase derivatives," Journal of Pharmacology and Experimental Therapeutics, vol. 298, no. 3, pp. 894-899, 2001.

[26] H. E. Poulsen, E. Specht, K. Broedbaek et al., "RNA modifications by oxidation: a novel disease mechanism?" Free Radical Biology and Medicine, vol. 52, no. 8, pp. 1353-1361, 2012.

[27] J. Hassler, S. S. Cao, and R. J. Kaufman, "IRE1, a Double-Edged Sword in Pre-miRNA Slicing and Cell Death," Developmental Cell, vol. 23, no. 5, pp. 921-923, 2012.

[28] J.-P. Upton, L. Wang, D. Han et al., "IRE1 $\alpha$ cleaves select microRNAs during ER stress to derepress translation of proapoptotic Caspase-2," Science, vol. 338, no. 6108, pp. 818-822, 2012.

[29] B. Ling and Z. Wei-Guo, "p53: structure, function and therapeutic applications," Journal of Cancer Molecules, vol. 2, no. 4, pp. 141-153, 2006.

[30] K. H. Vousden and X. Lu, "Live or let die: the cell's response to p53," Nature Reviews Cancer, vol. 2, no. 8, pp. 594-604, 2002.

[31] Z. Derdak, K. A. Villegas, R. Harb, A. M. Wu, A. Sousa, and J. R. Wands, "Inhibition of p53 attenuates steatosis and liver injury in a mouse model of non-alcoholic fatty liver disease," Journal of Hepatology, vol. 58, no. 4, pp. 785-791, 2013.

[32] Y. Wei, J. Gong, T. Yoshida et al., "Nrf2 has a protective role against neuronal and capillary degeneration in retinal ischemiareperfusion injury," Free Radical Biology and Medicine, vol. 51, no. 1, pp. 216-224, 2011.

[33] C. D. Klaassen and S. A. Reisman, "Nrf2 the rescue: effects of the antioxidative/electrophilic response on the liver," Toxicology and Applied Pharmacology, vol. 244, no. 1, pp. 57-65, 2010.

[34] S. A. Reisman, I. I. Csanaky, L. M. Aleksunes, and C. D. Klaassen, "Altered disposition of acetaminophen in Nrf2-null and keap1-knockdown mice," Toxicological Sciences, vol. 109, no. 1, pp. 31-40, 2009.

[35] S. Xu, J. Weerachayaphorn, S.-Y. Cai, C. J. Soroka, and J. L. Boyer, "Aryl hydrocarbon receptor and NF-E2-related factor 2 are key regulators of human MRP4 expression," American Journal of Physiology - Gastrointestinal and Liver Physiology, vol. 299, no. 1, pp. G126-G135, 2010.

[36] W. Tang, Y.-F. Jiang, M. Ponnusamy, and M. Diallo, "Role of Nrf2 in chronic liver disease," World Journal of Gastroenterology, vol. 20, no. 36, pp. 13079-13087, 2014.

[37] I. M. Copple, C. E. Goldring, N. R. Kitteringham, and B. K. Park, "The Nrf2-Keap1 defence pathway: role in protection against drug-induced toxicity," Toxicology, vol. 246, no. 1, pp. 24-33, 2008.

[38] P. Angulo, "Nonalcoholic fatty liver disease," New England Journal of Medicine, vol. 346, no. 16, pp. 1221-1231, 2002.

[39] F. I. Abdullaev, "Biological effects of saffron," BioFactors, vol. 4, no. 2, pp. 83-86, 1993.

[40] S. A. Mard, M. H. Pipelzadeh, A. Teimoori et al., "Protective activity of crocin against indomethacin-induced gastric lesions in rats," Journal of Natural Medicines, vol. 70, no. 1, pp. 62-74, 2016.

[41] P. Arda-Pirincci, S. Bolkent, and R. Yanardag, "The role of zinc sulfate and metallothionein in protection against ethanolinduced gastric damage in rats," Digestive Diseases and Sciences, vol. 51, no. 12, pp. 2353-2360, 2006.

[42] S. A. Mard, Z. Nikraftar, Y. Farbood, and E. Mansouri, "A preliminary study of the anti-inflammatory and anti-apoptotic effects of crocin against gastric ischemia-reperfusion injury in rats," Brazilian Journal of Pharmaceutical Sciences, vol. 51, no. 3, pp. 637-642, 2015.

[43] Y. Qi, L. Chen, L. Zhang, W.-B. Liu, X.-Y. Chen, and X.-G. Yang, "Crocin prevents retinal ischaemia/reperfusion injury-induced apoptosis in retinal ganglion cells through the PI3K/AKT signalling pathway," Experimental Eye Research, vol. 107, pp. 4451, 2013.

[44] Y.-Q. Zheng, J.-X. Liu, J.-N. Wang, and L. Xu, "Effects of crocin on reperfusion-induced oxidative/nitrative injury to cerebral microvessels after global cerebral ischemia," Brain Research, vol. 1138, no. 1, pp. 86-94, 2007.

[45] B. Naghizadeh, M. T. Boroushaki, N. Vahdati Mashhadian, and S. M. T. Mansouri, "Protective effects of crocin against cisplatininduced acute renal failure and oxidative stress in rats," Iranian Biomedical Journal, vol. 12, no. 2, pp. 93-100, 2008.

[46] B. Naghizadeh, S. M. T. Mansouri, and N. V. Mashhadian, "Crocin attenuates cisplatin-induced renal oxidative stress in rats," Food and Chemical Toxicology, vol. 48, no. 10, pp. 26502655, 2010.

[47] M. Askaripour, S. R. F. Tabatabaei, and F. Hosseini, "Effects of aqueous extract of purslane (Portulaca oleracea) on hepatic enzymes in two models of renal ischemia-reperfusion injury in rats," Zahedan Journal of Research in Medical Sciences, vol. 18, no. 2, Article ID e5995, 2015.

[48] J. A. Goss, P. Seu, F. Q. Gao, and S. Wyllie, "Ischemiareperfusion of rat liver modulates hepcidin in vivo expression," Liver Transplantation, vol. 11, no. 7, pp. 800-806, 2005.

[49] H. T. Lee, S. W. Park, M. Kim, and V. D. D’Agati, "Acute kidney injury after hepatic ischemia and reperfusion injury in mice," Laboratory Investigation, vol. 89, no. 2, pp. 196-208, 2009.

[50] A. A. Shokeir, N. Barakat, A. M. Hussein et al., "Activation of Nrf2 by ischemic preconditioning and sulforaphane in renal ischemia/reperfusion injury: a comparative experimental study," Physiological Research, vol. 64, no. 3, pp. 313-323, 2015.

[51] W. R. R. Farid, Q. Pan, A. J. P. van der Meer et al., "Hepatocytederived microRNAs as serum biomarkers of hepatic injury and rejection after liver transplantation," Liver Transplantation, vol. 18, no. 3, pp. 290-297, 2012.

[52] A. G. Bader, "miR-34-a microRNA replacement therapy is headed to the clinic," Frontiers in Genetics, vol. 3, 2012.

[53] N. Li, S. Muthusamy, R. Liang, H. Sarojini, and E. Wang, "Increased expression of miR-34a and miR-93 in rat liver during aging, and their impact on the expression of Mgstl and Sirtl," Mechanisms of Ageing and Development, vol. 132, no. 3, pp. 7585, 2011.

[54] X. Huang, Y. Gao, J. Qin, and S. Lu, "The role of miR$34 \mathrm{a}$ in the hepatoprotective effect of hydrogen sulfide on ischemia/reperfusion injury in young and old rats," PLOS ONE, vol. 9, no. 11, Article ID el13305, 2014.

[55] S. Thulasingam, C. Massilamany, A. Gangaplara et al., "miR$27 \mathrm{~b}^{\star}$, an oxidative stress-responsive microRNA modulates nuclear factor-kB pathway in RAW 264.7 cells," Molecular and Cellular Biochemistry, vol. 352, no. 1-2, pp. 181-188, 2011.

[56] J. He and B. H. Jiang, "Interplay between reactive oxygen species and MicroRNAs in cancer," Current Pharmacology Reports, vol. 2, no. 2, pp. 82-90, 2016.

[57] W. Zhang, M. Wang, H. Y. Xie et al., "Role of reactive oxygen species in mediating hepatic ischemia-reperfusion injury and its therapeutic applications in liver transplantation," Transplantation Proceedings, vol. 39, no. 5, pp. 1332-1337, 2007. 
[58] S. H. Kim, J. M. Lee, S. C. Kim, C. B. Park, and P. C. Lee, "Proposed cytotoxic mechanisms of the saffron carotenoids crocin and crocetin on cancer cell lines," Biochemistry and Cell Biology, vol. 92, no. 2, pp. 105-111, 2014.

[59] S. A. Mard, S. M. Azad, and A. Ahangarpoor, "Protective effect of crocin on gastric mucosal lesions induced by ischemiareperfusion injury in rats," Iranian Journal of Pharmaceutical Research, vol. 15, pp. 93-99, 2016.

[60] R. E. Castro, D. M. S. Ferreira, M. B. Afonso et al., "miR$34 \mathrm{a} / \mathrm{SIRT} 1 / \mathrm{p} 53$ is suppressed by ursodeoxycholic acid in the rat liver and activated by disease severity in human non-alcoholic fatty liver disease," Journal of Hepatology, vol. 58, no. 1, pp. 119125, 2013.

[61] A. Hau, P. Ceppi, and M. E. Peter, "CD95 is part of a let7/p53/miR-34 regulatory network,” PLoS ONE, vol. 7, no. 11, Article ID e49636, 2012.

[62] T.-C. Chang, E. A. Wentzel, O. A. Kent et al., "Transactivation of miR-34a by p53 broadly influences gene expression and promotes apoptosis," Molecular Cell, vol. 26, no. 5, pp. 745-752, 2007.

[63] W. Shan, L. Gao, W. Zeng et al., "Activation of the SIRT1/p66shc antiapoptosis pathway via carnosic acid-induced inhibition of MIR-34a protects rats against nonalcoholic fatty liver disease," Cell Death and Disease, vol. 6, no. 7, Article ID e1833, 2015.

[64] C. Abderrahim, "miR-34a-5p and miR-34a-3p contribute to the signaling pathway of $\mathrm{p} 53$ by targeting overlapping sets of genes," https://arxiv.org/abs/1608.02756.

[65] Z. Feng, C. Zhang, R. Wu, and W. Hu, “Tumor suppressor p53 meets microRNAs," Journal of Molecular Cell Biology, vol. 3, no. 1, pp. 44-50, 2011.

[66] S. Sözen, M. Kisakürek, F. Yildiz, M. Gönültas, and A. S. Dinçel, "The effects of glutamine on hepatic ischemia reperfusion injury in rats," Hippokratia, vol. 15, no. 2, pp. 161-166, 2011.

[67] M. Basbug, M. Yildar, I. Yaman et al., "Effects of boric acid in an experimental rat model of hepatic ischemia-reperfusion injury," Acta Medica Mediterranea, vol. 31, no. 5, pp. 1067-1073, 2015.

[68] Y.-W. Su, X. Chen, Z.-Z. Jiang et al., "A panel of serum microRNAs as specific biomarkers for diagnosis of compoundand herb-induced liver injury in rats," PLoS ONE, vol. 7, no. 5, Article ID e37395, 2012.

[69] T. Kodama, T. Takehara, H. Hikita et al., "Increases in p53 expression induce CTGF synthesis by mouse and human hepatocytes and result in liver fibrosis in mice," Journal of Clinical Investigation, vol. 121, no. 8, pp. 3343-3356, 2011.

[70] S. Palipoch and C. Punsawad, "Biochemical and histological study of rat liver and kidney injury induced by cisplatin," Journal of Toxicologic Pathology, vol. 26, no. 3, pp. 293-299, 2013.

[71] H. I. Suzuki, K. Yamagata, K. Sugimoto, T. Iwamoto, S. Kato, and K. Miyazono, "Modulation of microRNA processing by p53," Nature, vol. 460, no. 7254, pp. 529-533, 2009. 


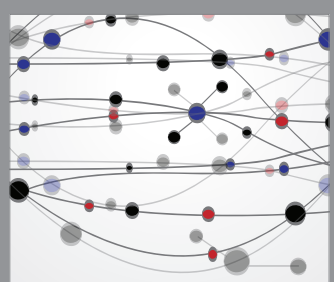

The Scientific World Journal
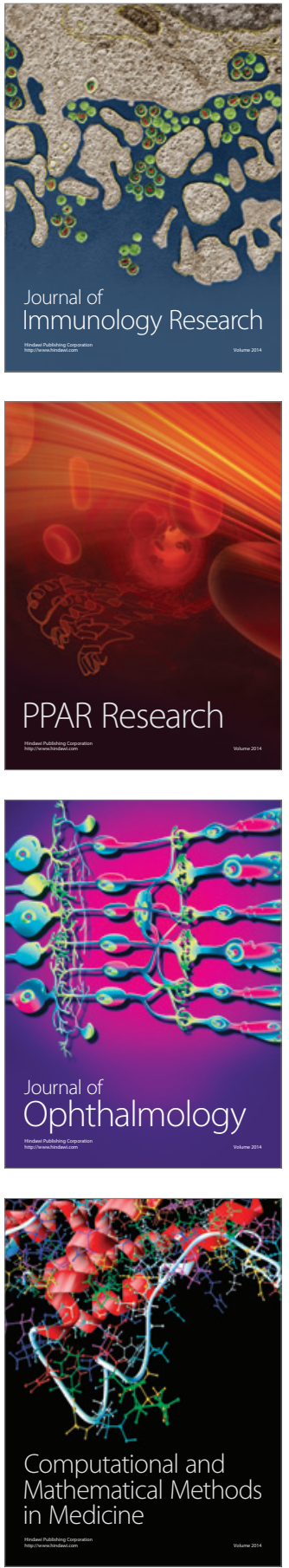

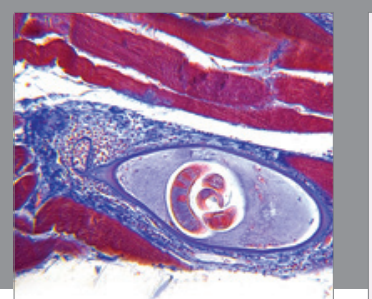

Gastroenterology Research and Practice
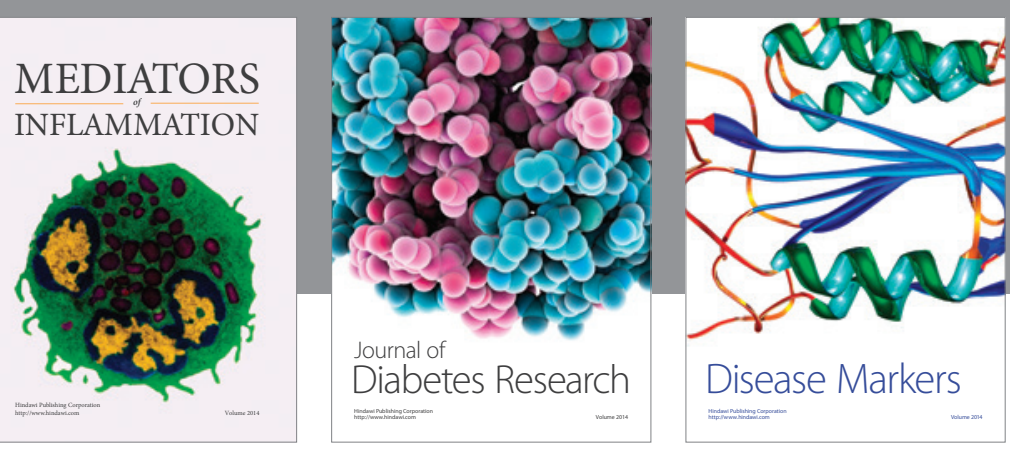

Disease Markers

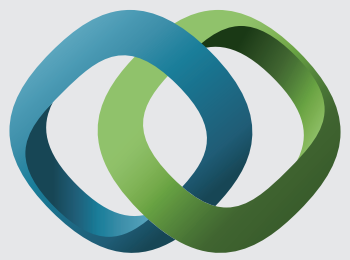

\section{Hindawi}

Submit your manuscripts at

https://www.hindawi.com
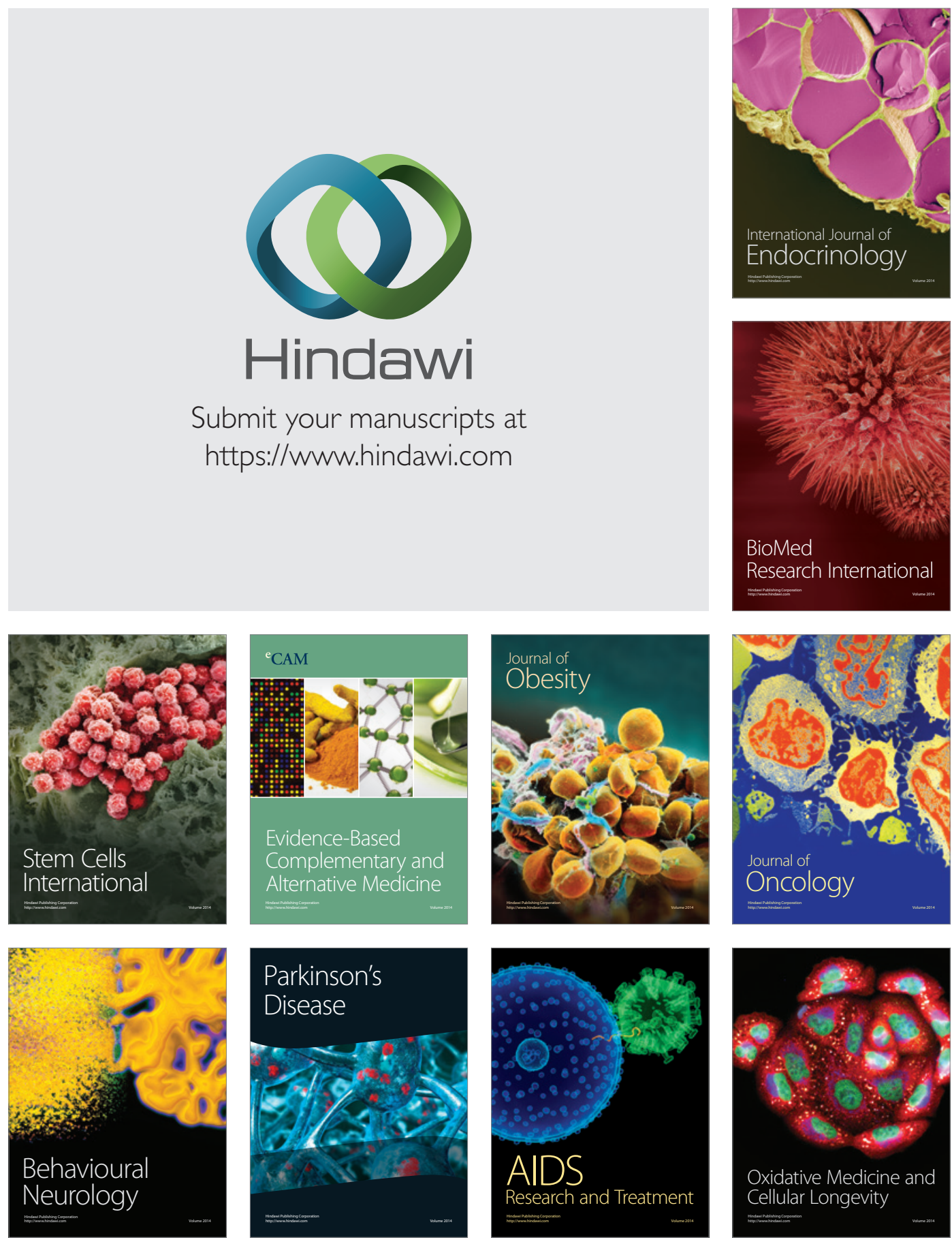